\title{
Adaptive Responses of Some Zygophyllum Species in Wadi Hagul, Egypt
}

\author{
Morsy, A.A. ${ }^{1}$, Youssef, A.M., Mosallam, H.A. and Gamal, E.A. \\ Faculty of science, Ain Shams University \\ Corresponding author; amalmorsy1570@,hotmail.com
}

Morsy,A.A., Youssef,A.M., Mosallam, H.A. and Gamal, E.A., 2014. Adaptive Responses of Some ZygophyllumSpecies in WadiHagul, Egypt. Taeckholmia 34: 77-99.

\begin{abstract}
$T_{\text {hree species, Zygophyllum coccineum L., Zygophyllum decumbens }}$ Delile and Zygophyllum simplex L., (Zygophyllaceae) were collected from three localities of Wadi Hagul in Egypt to study their adaptive responses to different environmental conditions. Plant analyses (degree of succulence, water content, total pigments, proline, antioxidant enzymes, total phenols, ascorbic acid, hydrogen peroxide and malondialdehyde) were estimated to study their roles in the adaptive responses of those plants under their natural drought conditions. Results have revealed that xerophytes can further be divided into two groups depending on their drought tolerance strategies. The first group includes perennial plants (Zygophyllum coccineum and Zygophyllum decembens) that able to tolerate and resurrect following desiccation into photosynthetically active states in a short period of time, the other is the dessication avoiding group; annual or biennial plant (Zygophyllum simplex), which possess an improved water-storing organ, efficient water conduction within the plant body and/or a combination of these features. Moreover, plants in this group (true xerophytes) are thought to have a unique system to cope with stress tolerance, since they are able to defend their photosynthetic apparatus and other fragile cellular components from composite stresses in the harsh environments in which they are found.
\end{abstract}

Key words: Drought, succulence, Zygophyllum, Wadi Hagul.

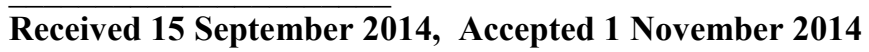




\section{Introduction}

Most plants are exposed to water stress due to extreme soil water deficits in arid and semi-arid environments. The survival of land plants in such areas relies on the availability of water and their adaptation under stress (Kramer, 1984). Drought resistance is a complex trait involving several interacting properties (Khan, 2003 and Scholz et al., 2012).

In arid and semi-arid regions, seasonal variations may lead to differential physiological responses in plants inhabiting such environments. Many studies have been cited on plant adaptations to high temperature, and salt stresses (Joyce et al., 1984; Murakeozy et al., 2003 and Kusaka et al., 2005).Ecophysiological studies have been investigated in elucidating plant function and identifying traits that are adaptive to specific environmental conditions (Ackerlyet al., 2000).

Wadis are the most widespread ecosystems in the mountainous desert of the world (Fossatiet al., 1999). The wadi system is an extreme case of a temporary inundated ecosystem in which the duration of flooding is shorter than the dry period (Evenari, 1985). Various habitats can be identified in a wadi: channels, bars, banks, etc. (Abdel Rahman and Batanouny, 1965). A wadi system embraces all the biotypes and related biocenases found in arid or hyper arid zones (Salamaet al., 2012).

Zygophyllum species represent a group of succulent plants which are drought resistant or salt tolerant living under severe dry climatic conditions (Batanouny and Ezzat, 1971). Succulent plants can survive under the severe water stresses depending on the stored water in their tissues (Maximov, 1929). They can reuse the large quantities of water they save (Nobel, 1977).

Therefore, in the present study we focus on the mechanisms of the adaptive responses of the studied Zygophyllumspecies in WadiHagul, Egypt (Z. coccineum,Z. simplex and Z. decumbens) in order to understand the ecophysiological adaptation traits by these plants. Accordingly, degree of succulence, water content, total pigments, proline, antioxidant enzymes, total phenols, ascorbic acid, hydrogen peroxide and malondialdehyde were estimated to investigate their roles in adaptation.

Z. coccineum L. is a succulent Shrub, up to $75 \mathrm{~cm}$; leaflets 2, bright green, glabrous, cylindrical, at least 10 mmlong; capsule $8-10 \mathrm{~mm}$, long and apex obtuse.Z. simplex L. is a glabrous, mat-shaped sappy herb with simple cylindrical leaves, 9-10 mm, long ; yellow flowers;capsule minute, only 2 $\mathrm{mm}$. deeply 5-parted.Z. decumbens Delile is a shrublet with prostrate or 
decumbent branches; leaves of one pair of broadly obovate, flattened, fleshy leaflets; flowers small, capsule pear-shaped, deeply 5-parted, apex entire (Boulos , 2000).

\section{Study area:}

WadiHagul is located in the northern portion of the Eastern Desert of

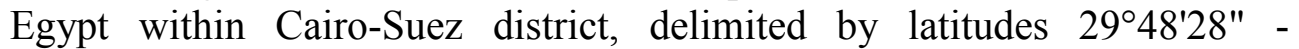

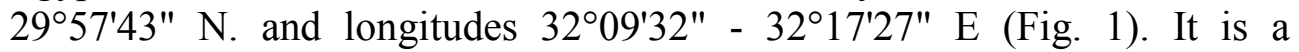
hydrographic wadi located in Suez Governorate (Egypt), the study location is situated $381 \mathrm{~km}$ north east of the approximate center of Egypt and $112 \mathrm{~km}$ east of the capital Cairo. It is one of the main drainage lines dissecting Gebel Ataqa (C.817m) when the tributaries of the southwestern and western slopes drain into this wadi (Zahran and Willis, 1992).

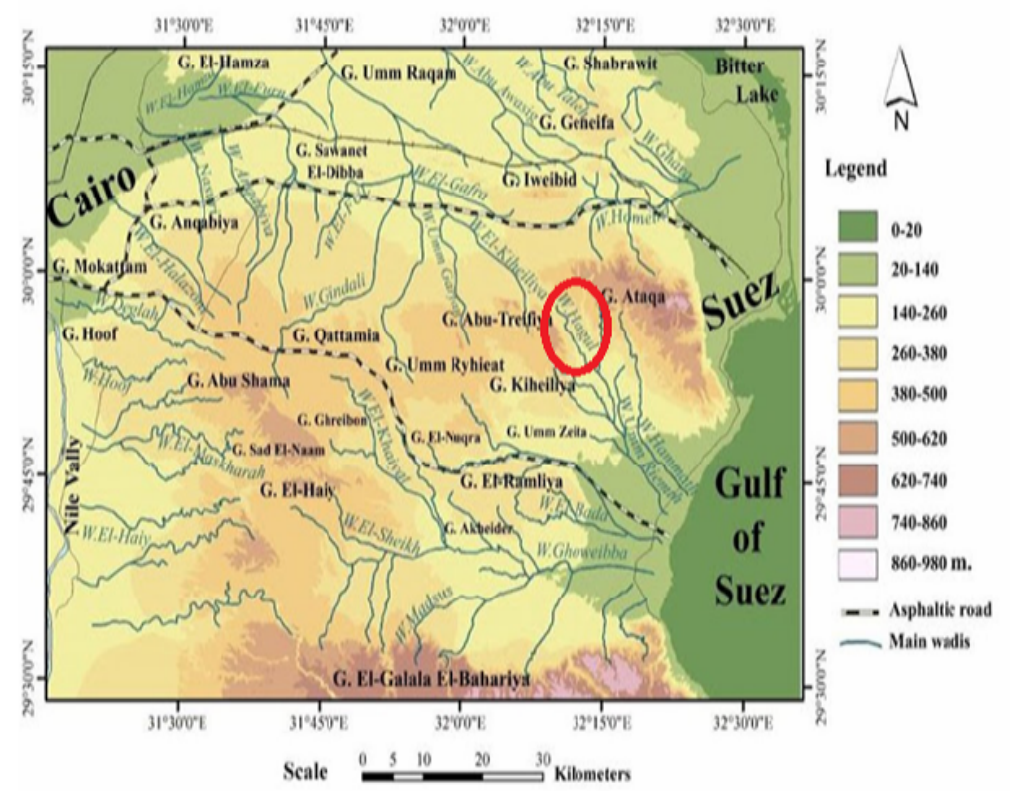

Fig.(1). Map of Cairo-Suez road showing the location of the studied site Wadi Hagul. 


\section{Materials and Methods}

Plant materials used in the present investigations are: The plant materials used in the present study were collected from three sites along wadi Hagul, each of them represent one stream of the wadi. The first studied plant is Zygophyllumcoccineum which is collected from upstream midstream and downstream sites along the study area, Z. simplexwas collected from two upstream and midstream, while Zygophyllumdecumbenswas collected from midstream and downstream.

\section{Soil analysis}

Soil samples were collected seasonally during dry and wet seasons at the surface $(0-20 \mathrm{~cm})$ and sub-surface $(20-40 \mathrm{~cm})$ depths. Some physical and chemical parameters of such soil samples were analyzed. Particle size (\%) was determined by the dry sieving to separate soil fractions according to Wentworth scale (Udden,1914; Wentworth, 1922;Krumbein and Sloss, 1963 and Ryan et al., 1996). Soil reaction $(\mathrm{pH})$ was determined in the soil solution 1:1 using a portable $\mathrm{pH}$-meter (Modellonlab $\mathrm{pH}$ level 1) (Richards, 1954). Electrical conductivity (EC) of the soil extracts was determined as described by Richards (1954) and expressed as mmhos. The anions and cations $\left(\mathrm{Cl}^{-}\right.$and $\left.\mathrm{K}^{+}\right)$of the soil extracts were analyzed following the method described by Richards(1954) and Rayan (1996) and their values expressed as meq Calcium carbonates was determined volumetrically using Collin's Calcimeter (Piper, 1950).

\section{Ecophysiological analysis:}

Degree of succulencewascarried out andcalculated according to Dehan and Tal (1978) and Ahmed and Shalaby (1985).The photosynthetic pigmentswere determined using spectrophotometric method (Metzneret al. 1965).Free proline contentwas estimated photometrically in an acid ninhydrin assay (Bates et al. 1973). For the determination ofoxidative enzyme activities(superoxide dismutase (SOD), catalase (CAT), peroxidase (POX), ascorbic acid oxidase (ASO) and polyphenol oxidase (PPO)),were extracted from fresh materials following Guerrier and Strullu(1990),CAT, POX and PPO activities were determined according to Kar and Mishra (1976), SOD activity was determined followingMarklund andMarklund(1974), while ASO activity was measured according to 
Diallinas et al. (1997). Total phenolswere determined following Malik and Singh(1980) whileascorbic acidwas estimated by the method of Mukherjee and Choudhury (1983), hydrogen peroxidecontentwas determined according to Velikova et al. (2000) and lipid peroxidation as indicated bymalondialdehyde (MDA)was estimated according to Hodges et al. (1999).

\section{Statistical analysis and data confirmation}

Data were statistically analyzed using the least significant difference (LSD) $(p<0.05)$ between mean values for the results of dry and wet seasons to compare significant differences. The computations were done y using SPSS software Version (16.0) .Values presented are means \pm standard deviation (SD) of three replicates.

\section{Results}

\section{Soil characteristics}

The soil texture of associated profile of the three studied locations was mainly formed of sand.Soil reaction $(\mathrm{pH})$ was slightly alkaline (Tables 1 and 2). In upstream location, the soil texture is sandy. Electric conductivity (E.C.) was high (1.1-1.4 $\mathrm{mmhosL}^{-1}$ ) at the surface soil layer indicating more soluble salts in the surface layer. The soil $\mathrm{pH}$ ranged between almost neutral to slightly alkaline (7.75-8.5). Cations showed higher $\mathrm{Ca}^{+2}\left(2.94 \mathrm{meq} \mathrm{L}^{-1}\right)$, $\mathrm{Mg}^{+2}\left(2.45 \mathrm{meq} \mathrm{L} \mathrm{L}^{-1}\right), \mathrm{Na}^{+}(6.33 \mathrm{meq})$ and $\mathrm{K}^{+}\left(0.23 \mathrm{meq} \mathrm{L}^{-1}\right)$ during dry season. Anions revealed higher $\mathrm{Cl}^{-}\left(8.33 \mathrm{meq} \mathrm{L}^{-1}\right)$ and $\mathrm{HCO}_{3}{ }^{-}\left(1.66 \mathrm{meqL}^{-1}\right)$ during dry season, while $\mathrm{SO}_{4}^{-2}$ was relatively low $\left(3.81 \mathrm{meqL}^{-1}\right)$, calcium carbonate was ranged between 15.5 to 5.7, attained comparatively higher values in dry season. In midstream location, the soil texture is sandy, soil reaction is tended tobe slightly alkaline (7.52-8.4), E.C. amounted to $2.36 \mathrm{mmhos}$ during dry season in the upper layer. Cations prevailing were $\mathrm{Na}^{+}(12.9$ $\left.\mathrm{meqL}^{-1}\right), \mathrm{Ca}^{+2}\left(6.24 \mathrm{meqL}^{-1}\right)$ followed by $\mathrm{Mg}^{+2}\left(4.16 \mathrm{meqL}^{-1}\right)$ reached highest contents among all the studied soil profile during dry season, but $\mathrm{K}^{+}\left(0.35 \mathrm{meqL}^{-1}\right)$ is of low content.Prevailing anions are mostly $\mathrm{Cl}^{-}(19.5$ meqL $\left.{ }^{-1}\right)$ followed by $\mathrm{SO}_{4}^{-2}\left(9.1 \mathrm{meqL}^{-1}\right)$. Soil texture at the downstream location isgravely at $20-40 \mathrm{~cm}$, while $0-20 \mathrm{~cm}$ layer isalmostlysandy with gravel fractions. The E.C. ranged between $0.25 \mathrm{mmhos}$ in upper layer $(0-20$ $\mathrm{cm})$ to 0.14 mmhos at depth $(20-40 \mathrm{~cm})$ during dry season. The cation content decreased with increase depth till $40 \mathrm{~cm}$ during dry season. Anion of chlorides $\left(0.95 \mathrm{meqL}^{-1}\right)$ surpassed sulphates $\left(0.89 \mathrm{meqL}^{-1}\right)$. 


\section{Degree of succulence and Water content}

Both parameters were greater in plants collected in wet season than in plants collected in dry season.Zygophyllum decumbens collected during wet season from midstream location attained the highest degree of succulence (4.7) and water content (79.7) which showed significant difference from the same plant collected from the same location in dry season.(Table 3).

\section{Photosynthetic pigments}

Zygophyllum simplex collected from midstream location(during wet season) showed the highest total pigments(13.71mg/g f.wt of leaves), while Zygophyllumcoccineum collected from upstream location (during dry season)showed the lowest value (4.4 $\mathrm{mg} / \mathrm{g}$ f.wt of leaves).(Table 4).

\section{Proline}

It has been shownin Table (5) that;proline content increased in dry season than in wet season showing significant difference. Zygophyllum coccineum collected from upstream location(during dry season) showed the highest proline content $(115.97 \mu \mathrm{g} / \mathrm{g}$ f.wt), while Zygophyllum simplex collected from midstream location (during wet season) showed the lowest value $(43.62 \mu \mathrm{g} / \mathrm{g}$ f.wt).It is noticeable that, the midstream location showed the lowest proline content in all species compared with other locations.

\section{Antioxidant enzymes}

The activity of these enzymes was significantly increased during dry season in the three studied species (Table 6). The activity of all enzymes decreased obviously in mid stream location in all three species.

The activity of SOD showed its highest value within Zygophyllumdecumbens in downstream location (35.87unit /mg protein), while the least value within Zygophyllumcoccineum in downstream location (3unit /mg protein).

The activity of CAT showed the highest value with Zygophyllumdecumbens in downstream location $(149.17 \mu \mathrm{molH} 2 \mathrm{O} 2$ destroyed / g f.wt / $\mathrm{min}$ ), while the lowestvalue is recorded with Zygophyllum coccineumin midstream location $(3.7 \mu \mathrm{mol} \mathrm{H} 2 \mathrm{O} 2$ destroyed / $\mathrm{g}$ f.wt / $\mathrm{min})$.

The activity of Peroxidase (POD) showed the highest value with Zygophyllumdecumbens in downstream location (84.3 g f.wt/min.), while 
the lowest value is recorded within Zygophyllum coccineum in midstream location (0.13 g f.wt / $\mathrm{min}$.).

The activity of ASO showed the highest value with Zygophyllum decumbens in downstream location $(12.1 \mathrm{mM}$ of ascorbate oxidized $/ \mathrm{g}$ f.wt/min.), while the lowest value is recorded with Zygophyllum coccineum in midstream location $(0.17 \mathrm{mM}$ of ascorbate oxidized $/ \mathrm{g} \mathrm{f.wt} / \mathrm{min})$.

The activity of PPO showed the highest value with Zygophyllum coccineumin upstream location $(53.98 \mathrm{~g}$ f.wt $/ \mathrm{min}$.), while the lowest value is recorded within the same species in midstream location $(49.52 \mathrm{~g} \mathrm{f.wt} / \mathrm{min}$.).

\section{Total phenols and Ascorbic acid}

Total phenols show the same behavior as ascorbic acid, as the content increased in wet season than in dry one.Zygophyllum decumbent in midstream location had the highest total phenols content $(1.71 \mathrm{mg} / \mathrm{g}$ f.wt), while Zygophyllum coccineum in upstream showed the lowest content (0.48mg / g f.wt). Zygophyllum coccineum located in midstream revealed the highest ascorbic acid content $(499.54 \mathrm{mg} / 100 \mathrm{~g}$ f.wt) and Zygophyllum simplex in upstream showed the lowest content $(152.45 \mathrm{mg} / 100 \mathrm{~g}$ f.wt).

\section{Hydrogen peroxide and Malondialdehyde contents}

Zygophyllum decumbens collected from downstream location (during dry season) showed the highest hydrogen peroxide content among all plants $(219.01 \mathrm{mM} / \mathrm{g}$ f.Wt),while Zygophyllum simplex collected from midstream location (during wet season) showed the lowest value $(111.37 \mathrm{mM} / \mathrm{g}$ f.Wt), which in case of malondialdehyde showed the same behavior $(0.103 \mathrm{nmol} / \mathrm{g}$ f.wt), whereas Zygophyllum coccineum collected from upstream location (during dry season) showed the highest malondialdehyde content among all plants $(0.95 \mathrm{nmol} / \mathrm{g}$ f.wt $)$

\section{Discussion}

\section{Soil characteristics}

Soil factors play important role in plant growth, chemical composition and distribution of plants under different habitat conditions. In the present study soil samples supporting the growth of the different studied species, were collected from the sites where the three selected Zygophyllum species (Zygophyllum coccineum, Zygophyllum decumbens and Zygophyllum simplex) grown.

The three studied locations lie successively declining contours from the upstream to the downstream of Wadi Hagul. The inclination angle of the 
slope of the wadi course is quite noticeable and consequent features of soil erosion and deposition occur along the wadi course.

The soils of the studied areas are aridisols (dry, desert-like soils) or entisols (weakly-developed soils); characterized by weak profile development, coarse texture, low moisture content, low nutritional content and slightly alkaline or neutral reaction.(Zaki, 1995).

\section{Degree of succulence and Water content}

This may be due to the morphological and anatomical characteristics of this plant. This conclusion coincided with Walyet al., (2011), who studied the anatomical characteristics of the three studied Zygophyllum species in this work.Succulence is considered as mechanism through which plants are adapted to adverse environmental conditions including salinity and drought (Ahmed and Shalaby, 1985 and Morsy, 1996; 2002).

Species of the genus Zygophyllum are among the succulent xerophytes which can withstand the adverse conditions of the desert environments; shortage of water, scorching temperature and likely soil salinity (Kassas and Batanouny, 1984). Zaki (1995) indicated that Zygophyllum coccineum attained the lowest degree of succulence in summer. It might be associated with a decrease in moisture availability in which resulted in a decrease in total available carbohydrates and nitrogen uptake.

\section{Photosynthetic pigments}

All species showed decreasing in photosynthetic pigments in dry season, as plants lose their pigments due to drought conditions of their habitats and they may have another strategy to overcoming drought rather than pigment accumulation. These results are in accordance with Wingler et al. (1999), it is reported that the combined effects of heat and light stress on photosynthesis superimposed with drought will be more complex. Under these conditions, plants are known to lose chlorophyll (Havaux and Tardy, 1999). Moreover, drought not only causes dramatic loss of pigments, but also leads to disorganization of thylakoid membranes (Ladjal et al., 2000).

\section{Proline}

Accumulation of the amino acid proline is one of the most frequently reported modifications induced by water deficit, salt, and waterlogging stresses in plants and is thought to be involved in stress tolerance 
mechanisms, although its precise role remains controversial (Gadallah, 1995; Lutts et al., 1999 and Yiu et al., 2009).

The plant free proline massive accumulated when the plants subject to drought stress, is due to decrease inproline dehydrogenase activity is decreased and weaken in proline oxidation; drought suppressed the protein synthesis, decreased proline utilization and increasedproline accumulation in plants (Zhan et al., 2011).

\section{Antioxidant enzymes}

To mitigate the oxidative damage initiated by ROS (during dryseason), Zygophyllum spp. developed a complex defense antioxidative system including low molecular mass antioxidant, hydrogen peroxide, proline as well as antioxidant enzymes; ASO, SOD, CAT, PPO and POD.

SOD is the front line enzyme in ROS attack since it rapidly scavenges superoxide, one of the first ROS to be produced, dissimulating it to oxygen and $\mathrm{H}_{2} \mathrm{O}_{2}$ (Bowler, 1992).However, this reaction only converts one ROS to another, and $\mathrm{H}_{2} \mathrm{O}_{2}$ also needs to be destroyed since it promptly attacks thiol proteins.

The major enzymatic cellular scavengers of $\mathrm{H}_{2} \mathrm{O}_{2}$ are catalase and ascorbate peroxidase (Noctor, 1998). They have however different affinities for this ROS and seem to have different cellular roles in $\mathrm{H}_{2} \mathrm{O}_{2}$ scavenging. SOD controls the first threshold of the water-water cycle of antioxidant system (Asada, 1999 and Zhu et al., 2009a). It plays a key role in quenching active oxygen (Fu and Huang, 2001), working as catalyzing the dismutation of $\mathrm{O}_{2}{ }^{-}$into $\mathrm{H}_{2} \mathrm{O}_{2}$ which are eliminated by CAT, POD and other antioxidant enzymes.

Catalases and peroxidases (CAT and POD) play an essential role in scavenging for $\mathrm{H}_{2} \mathrm{O}_{2}$ toxicity. The combined action of CAT and SOD converts the toxic superoxide radical $\left(\mathrm{O}_{2}^{-}\right)$and hydrogen peroxide $(\mathrm{H} 2 \mathrm{O} 2)$ to water and molecular oxygen $\left(\mathrm{O}_{2}\right)$, thus averting the cellular damage under unfavorable conditions like drought stress (Noctor et al., 2000; Reddy et al., 2000 and Chaitanya et al., 2002).

The activities of CAT $(9.35 \mathrm{U} \cdot \mathrm{g}-1 \cdot \mathrm{min}-1)$ and POD (257.53 U.g-1 $\cdot \mathrm{min}-1)$ were higher in Caraganakorshinskiicompared to the other four desert plants (Calligonum mongolicum, Haloxylon ammodendron, Nitraria sphaerocarpa and Tamarix ramosissima) and increase in CAT and POD activity helps to overcome the damage of tissue metabolism by reducing the toxic level of $\mathrm{H}_{2} \mathrm{O}_{2}$ (Zhou et al., 2013). 
Regarding the activities of the antioxidant enzymes it is apparent that, there is a direct relation between activities of those enzymes and the climatic conditions and edaphic factors of soil (Table 2), the midstream location was rich in the percentage of silt and clay, cations and anions as compared with other upstream and downstream locations.

A common effect of drought stress is the disturbance between the generation and quenching of reactive oxygen species (ROS) (Smirnoff, 1998).

\section{Total phenols and Ascorbic acid}

The accumulation of phenolic compounds varies strongly with the growth state, development and responses to environmental stresses and is a result of balance between biosynthesis and further catabolism (Korkina, 2007).

Ascorbic acid (ASC) is the primary water-soluble antioxidant in plants and animals (Levine et al., 1995 and Siesand Stahl, 1995).Ascorbate is a major soluble redox molecule with pivotal roles in allowing several metabolic pathways towork properly. ASC regenerates other metabolites, among which tocopherols, from oxidative damages and protects the catalytic site of a number of enzymes (e.g., hydroxylases) from irreversible oxidation, possibly caused by reactive oxygen species (ROS) in both animal and plant cells. It can be used as substrate or enzyme cofactor in various biological reactions (Lodge, 2008 and De Gara et al., 2010).

Enzymatic ASC oxidation mainly occurs in plants through the reactions catalyzed by ascorbate oxidase (AOX) and ASC peroxidase (APX), two typical plant enzymes. AOX is an apoplastic enzyme involved in cell elongation (Takahama and Oniki, 1994). The down-regulation of this enzyme causes a shift in the apoplastic ASC pool toward its reduced state; it also increases plant yield during water deficit, through a carbon flux reallocation, but does not determine a significant ASC increase in the investigated tissues (Garchery et al., 2013). The ascorbic acid content of plants is observed to be reduced by water stress (Abdel-Kader, 2001; Manivannan et al., 2007 and Nair et al., 2008). Water stress caused significant reduction of the ascorbic acid of the leaves of Gongronem alatifolium (Osuagwu,2012).

Generally, increasing in total phenols and ascorbic acid during wet season may be due to prepare for the dry season. 


\section{Hydrogen peroxide and Malondialdehyde}

It has been shown that hydrogen peroxide and malondialdehyde content increased in dry season than in wet season showing significant difference. The midstream location showed the lowest hydrogen peroxide and malondialdehyde content in all species compared with other locations.

Malonyldialdehyde (MDA) is a product of lipid peroxidation- content has been considered as an indicator of oxidative damage (Neto et al., 2006).

The formation of MDA was considered as a measure of lipid peroxidation that was induced by a high water stress level (Jones, 1999). MDA, a decomposition product of polyunsaturated fatty acid hydroperoxides, has been utilized very often as a suitable biomarker for oxidative stress. Usually the increase in lipid peroxidation was simultaneously accompanied by an increase in hydrogen peroxide levels.

Zygophyllum decembens, in this studyshowed highcapacity to adapt to the surrounding circumstances; by increasing some antioxidant enzymes (ASO), (SOD), (CAT) and (POD), and hydrogen peroxide during dry season and degree of succulence during wet season. Meanwhile, Zygophyllum coccineum increased proline, PPO and malondialdehyde during dry season and ascorbic acid during wet season, whereas, Zygophyllum simplex increased total pigments and total phenols during wet season.

Tahle (1). Gr arndim etric andysis of soil profiles associated with the studied species

\begin{tabular}{|c|c|c|c|c|c|c|c|c|c|}
\hline \multirow{2}{*}{ Associated plants } & \multirow{2}{*}{ Depth } & $\begin{array}{c}\text { Wery } \\
\text { fime } \\
\text { gavel } \\
(\%)\end{array}$ & $\begin{array}{l}\text { Tery } \\
\text { cosise } \\
\operatorname{sand} \\
(\%)\end{array}$ & $\begin{array}{l}\text { Coure } \\
\text { sand } \\
(\%)\end{array}$ & $\begin{array}{l}\text { Medim } \\
\sin (\%)\end{array}$ & $\begin{array}{c}\text { Fime sand } \\
(\%)\end{array}$ & $\begin{array}{l}\text { Tery fine } \\
\operatorname{sand}(\%)\end{array}$ & $\begin{array}{l}\operatorname{Silt} 8 \\
\text { Clay } \%\end{array}$ & \\
\hline & & $\begin{array}{l}(4-2 \\
m+m)\end{array}$ & $\begin{array}{l}(2-1 \\
m m)\end{array}$ & (1-0.5 & $\begin{array}{l}0.5 \\
0.25 \\
m+m)\end{array}$ & $\begin{array}{c}(0.25-0.125 \\
\mathrm{mm})\end{array}$ & $\begin{array}{c}(0.1250 .63 \\
m+1)\end{array}$ & $\begin{array}{c}(0.00 \\
\mathrm{mm})\end{array}$ & Texture \\
\hline 7pgoplilumonomeum & $0-20$ & 128 & 866 & 1622 & 8.72 & 21.89 & 9.7 & 392 & Sandy \\
\hline 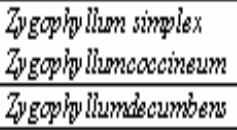 & $\begin{array}{l}20-40 \\
0-20\end{array}$ & $\begin{array}{l}72 \\
2.2\end{array}$ & $\begin{array}{l}11.96 \\
4.28\end{array}$ & $\begin{array}{l}24.95 \\
1698\end{array}$ & $\begin{array}{l}40.59 \\
289\end{array}$ & $\begin{array}{l}11.7 \\
27.64\end{array}$ & $\begin{array}{l}2.11 \\
14.91\end{array}$ & $\begin{array}{l}1.4 \\
5.04\end{array}$ & $\begin{array}{l}\text { Sandy } \\
\text { Sandy }\end{array}$ \\
\hline Zygoplingm simplex & $20-40$ & 38 & 525 & 11.55 & 336 & 32.27 & 88 & 4.6 & Sandy \\
\hline 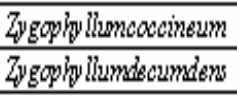 & $0-2$ & 21.0 & 19.77 & 2364 & 17.09 & 980 & 4.15 & 3.5 & Sandy \\
\hline & 2040 & 51.27 & 24.66 & 13.12 & 5.45 & 3.57 & 1.19 & 0.74 & Gravely \\
\hline
\end{tabular}




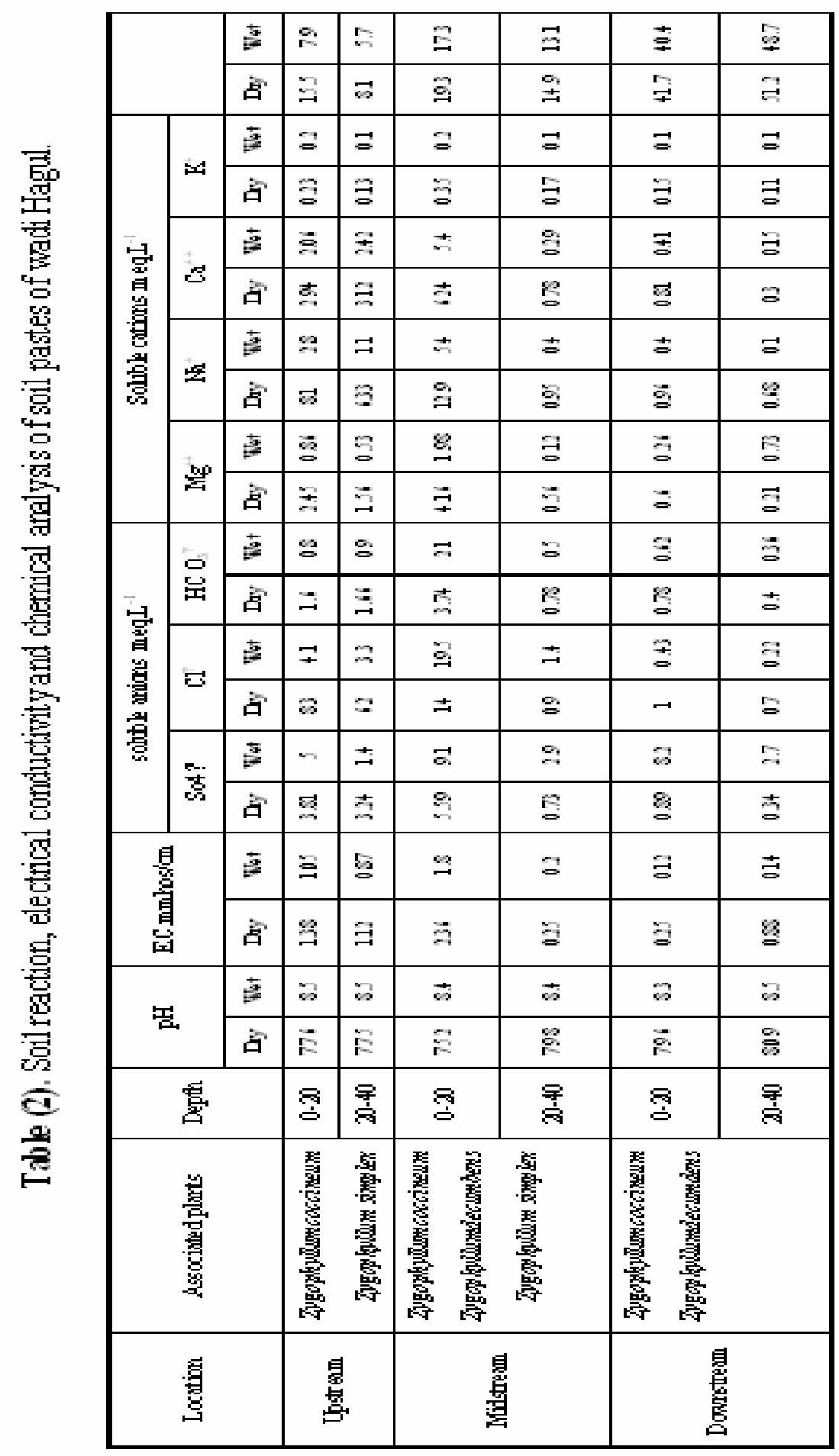


Table (3). Seasonal fluctuations inDegree of succulence of the studied.

\begin{tabular}{|c|c|c|c|c|c|}
\hline \multirow[t]{2}{*}{ Plant species } & \multirow[t]{2}{*}{ Location } & \multicolumn{2}{|c|}{ Degree of succulence } & \multicolumn{2}{|c|}{ Water content } \\
\hline & & Dry & Wet & Dry & Wet \\
\hline \multirow[t]{3}{*}{$\begin{array}{l}\text { Zygophyllum } \\
\text { coccineum }\end{array}$} & Upstream & $\begin{array}{c}3.36 \pm 0 \\
02\end{array}$ & $\begin{array}{l}3.64 \pm 0.12 \\
\text { (s) }\end{array}$ & $70.22 \pm 0.20$ & $\begin{array}{c}73 \pm 0.22 \\
\text { (s) }\end{array}$ \\
\hline & Midstream & $\begin{array}{c}4.08 \pm 0 . \\
01\end{array}$ & $\begin{array}{c}4.46 \pm 0.02 \\
(\mathrm{~s})\end{array}$ & $75.48 \pm 0.08$ & $\begin{array}{c}77.58 \pm 0.08 \\
(\mathrm{~s})\end{array}$ \\
\hline & downstream & $\begin{array}{c}3.57 \pm 0 \\
05\end{array}$ & $3.79 \pm 0.03$ & $72.03 \pm 0.38$ & $\begin{array}{c}73.6 \pm 0.18 \\
(\mathrm{~s})\end{array}$ \\
\hline \multirow{2}{*}{$\begin{array}{l}\text { Zygophyllum } \\
\text { simplex }\end{array}$} & Upstream & $\begin{array}{c}2.92 \pm 0 \\
07\end{array}$ & $2.98 \pm 0.04$ & $65.82 \pm 0.78$ & $66.7 \pm 0.18$ \\
\hline & Midstream & $3 . \pm 0.01$ & $3.24 \pm 0.24$ & $68 \pm 1$ & $\begin{array}{c}69.67 \pm 0.58 \\
\text { (s) }\end{array}$ \\
\hline \multirow[t]{2}{*}{$\begin{array}{l}\text { Zygophyllum } \\
\text { decumbens }\end{array}$} & Midstream & $\begin{array}{c}4.04 \pm 0 . \\
04\end{array}$ & $\begin{array}{c}4.68 \pm 0.43 \\
\text { (s) }\end{array}$ & $75.27 \pm 0.25$ & $\begin{array}{c}79.73 \pm 0.13 \\
\text { (s) }\end{array}$ \\
\hline & downstream & $\begin{array}{c}2.05 \pm 0 \\
01\end{array}$ & $\begin{array}{c}3.25 \pm 0.13 \\
\text { (s) }\end{array}$ & $51.13 \pm 0.32$ & $\begin{array}{c}67.58 \pm 1.9 \\
\text { (s) }\end{array}$ \\
\hline
\end{tabular}




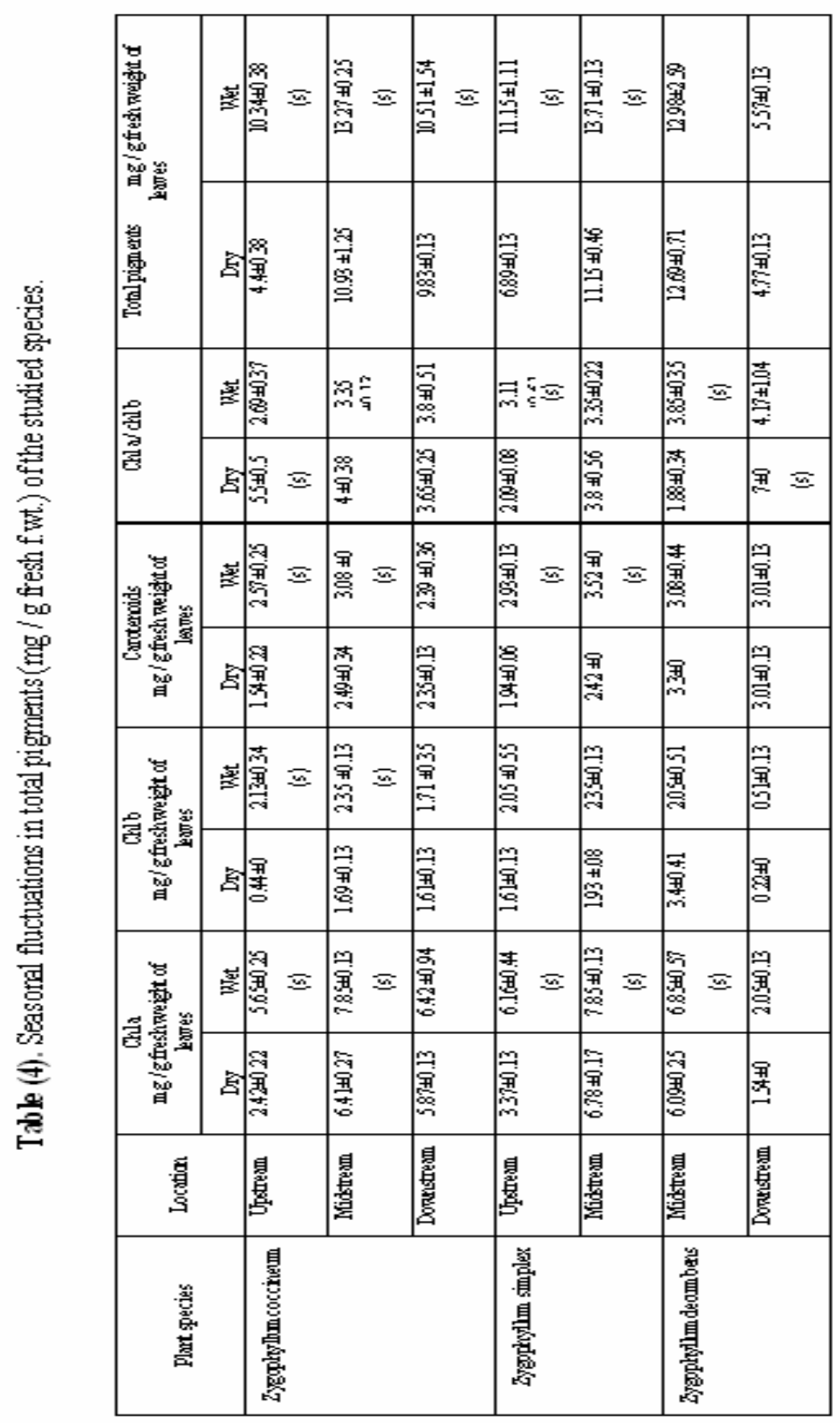


Table (5). Seasonal fluctuations in Proline ( $\mu \mathrm{g} / \mathrm{g}$ f.wt.) of the studied species.

\begin{tabular}{|l|c|c|c|}
\hline \multirow{2}{*}{ Plant species } & \multirow{2}{*}{ Location } & \multicolumn{2}{|c|}{ Proline $\boldsymbol{\mu g}$ / g fresh weight } \\
\cline { 3 - 4 } & Upstream & $\begin{array}{c}115.97 \pm 1.68 \\
(\mathrm{~s})\end{array}$ & $82.91 \pm 0.97$ \\
\hline \multirow{3}{*}{$\begin{array}{l}\text { Zygophyllum } \\
\text { coccineum }\end{array}$} & Midstream & $\begin{array}{c}53.88 \pm 1.27 \\
(\mathrm{~s})\end{array}$ & $50.2 \pm 0.19$ \\
\cline { 2 - 4 } & Downstream & $\begin{array}{c}113.74 \pm 0.94 \\
(\mathrm{~s})\end{array}$ & $78.06 \pm 1.91$ \\
\cline { 2 - 4 } & Upstream & $\begin{array}{c}88.06 \pm 2.08 \\
(\mathrm{~s})\end{array}$ & $81.28 \pm 2.15$ \\
\hline \multirow{2}{*}{$\begin{array}{l}\text { Zygophyllum } \\
\text { simplex }\end{array}$} & Midstream & $\begin{array}{c}46.1 \pm 0.6 \\
(\mathrm{~s})\end{array}$ & $43.62 \pm 0.66$ \\
\hline \multirow{2}{*}{$\begin{array}{l}\text { Zygophyllum } \\
\text { decumbens }\end{array}$} & Midstream & $\begin{array}{c}77.57 \pm 0.95 \\
(\mathrm{~s})\end{array}$ & $62.49 \pm 1.21$ \\
\cline { 2 - 4 } & Downstream & $\begin{array}{c}111.78 \pm 0.88 \\
(\mathrm{~s})\end{array}$ & $77.09 \pm 1.30$ \\
\hline
\end{tabular}


92

Morsy, A.A. et al.

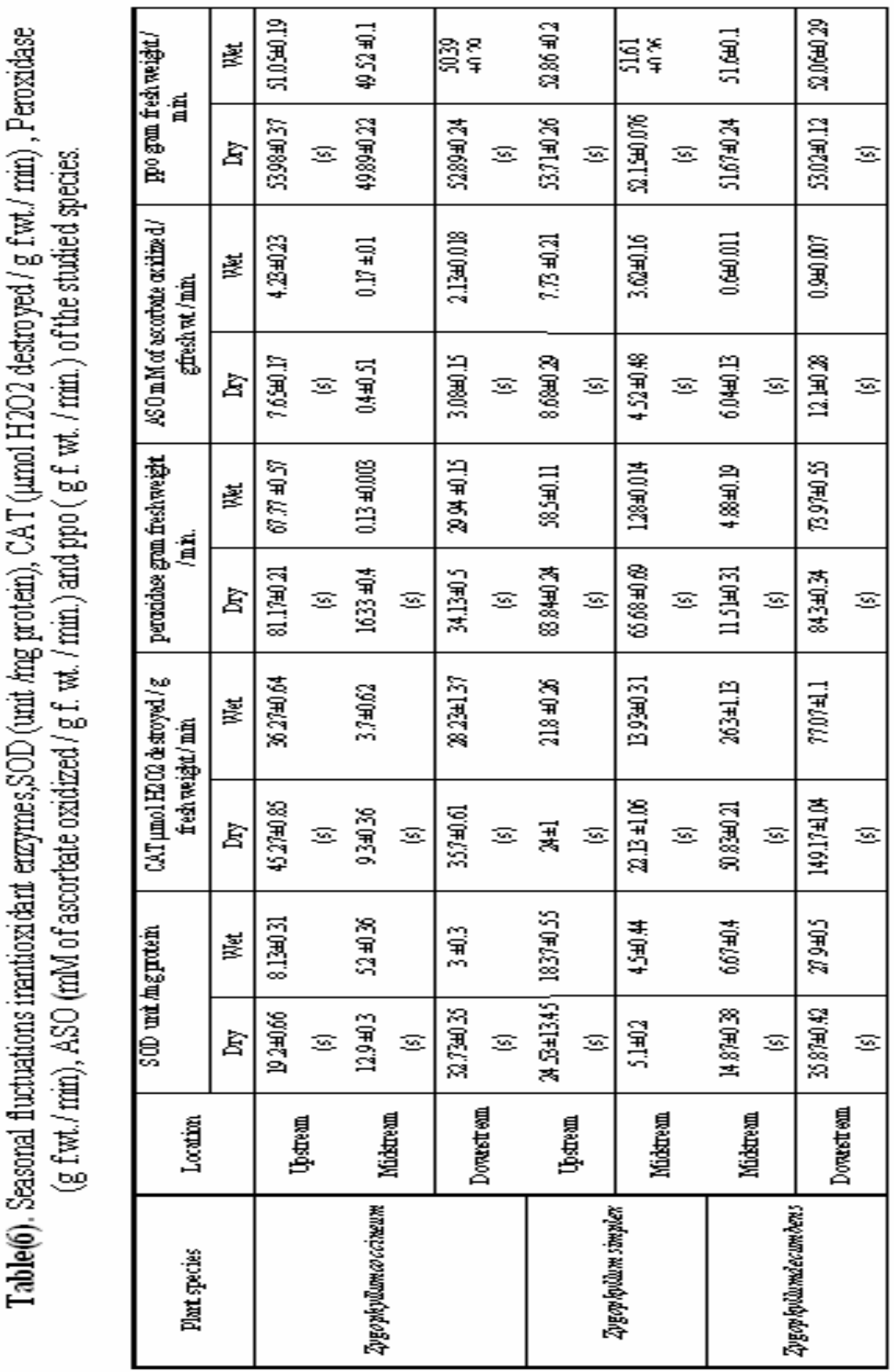




\begin{tabular}{|c|c|c|c|c|c|c|c|}
\hline \multirow{2}{*}{ 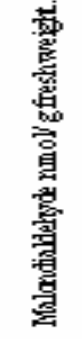 } & 悉 & 䨓 & 瞢 & 突 & 恶 & 鲟 & 䍜 䍜 \\
\hline & 察 & 萝 & 签 & 害心 & 莺 & 魚 & 番兽 \\
\hline \multirow{2}{*}{ 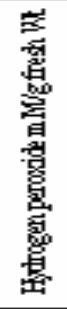 } & 荬 & 箒 & 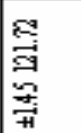 & 蜳 & 莤 & $\begin{array}{l}\overrightarrow{7} \\
\text { 莕 } \\
\text { s }\end{array}$ & $\begin{array}{ll}\text { 营 } & \text { 夢 } \\
\text { 总 } & \text { 总 }\end{array}$ \\
\hline & 宫 & 覃 & 总 & 蛋 & 䇥 & 急 & 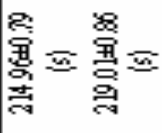 \\
\hline \multirow{2}{*}{ 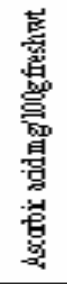 } & 蒡 & 密 & 篝 & 譬 & 舅 & 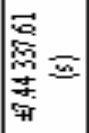 & 营心䔡心 \\
\hline & 宫 & 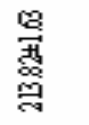 & $\begin{array}{l}\text { 㽦 } \\
\text { 学 }\end{array}$ & 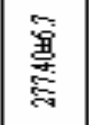 & 急 & 窎 & 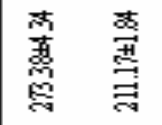 \\
\hline \multirow{2}{*}{ 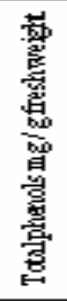 } & 荬 & 蒙 & 毁 & 躉 & 莺 & 穿 & $\begin{array}{l}\text { 高 } \\
\text { 票 }\end{array}$ \\
\hline & 点 & 嘦 & 鮙 & 莺 & 尋 & 富 & 䙶 罳 \\
\hline \multicolumn{2}{|c|}{ 暮 } & 瞌 & 鼻 & 罍 & 悬 & 基 & 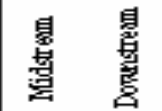 \\
\hline \multicolumn{2}{|c|}{ 裳 } & \multicolumn{3}{|c|}{ 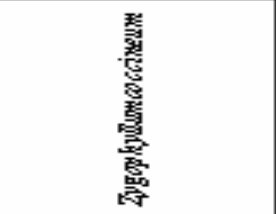 } & \multicolumn{2}{|c|}{ 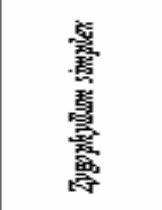 } & 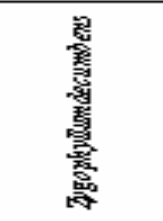 \\
\hline
\end{tabular}




\section{References}

Abd El-Rahman, A.A. and Batanouny, K.H. (1965): Transpiration of desert plants under different environmental conditions. J. Ecol. 55: 267272.

Abdel-Kader, D.Z.(2001): Drought and gibberellic acid-dependent antioxidant defense system in two lettuce cultivars.Pakistan J. Biol. Sci. 4(9):1138-1147.

Ackerly, D.D., Dudley, S.A., Sulton, S.E., Schmitt, J., Coleman, J.S. and Linder,C.R.(2000): The evolution of plant ecophysiological traits: recent advances and future directions. Bioscience 50: 979-995.

Ahmed, A.M. and Shalaby, A.A. (1985): Ecophysiological responses of Zygophyllum album L. and Nitrariaretusa Asch. Under different habitat conditions of Sinai, Egypt.Desert Inst. Bull. A.R.E. 35(2): 609-624.

Asada, K. (1999): The water-water cycle in chloroplasts: scavenging of active oxygens and dissipation of excess photons. Annu. Rev. Plant Physiol. Plant Mol. Biol. 50:601-639.

Aziz I and Khan A. (2003):Proline and water status of some desert shrubs before and after rain. Pakistan J. Bot. 35: 902-906.

Batanouny,K.H.and Ezzat,N.H (1971):Ecophysiological studies on desert plants. I. Autecology of EgyptianZygophyllum species. Oecologia 7: 170-183.

Bates, L.S., Waldren,R.P. andTeare,I.D.(1973): Rapid determination of free proline for water stress studies. Plant and Soil.39: 205-207.

Boulos, L. (2000): Flora of Egypt 2: 13-22. Al Hadara Publishing, Cairo.

Bowler,C., Van,M. and Inze,D.(1992):Superoxide dismutase and stress tolerance. Annu. Rev. Plant Physiol. Plant Mol. Biol., 43: 83-116.

Chaitanya, K.V., Sundar, D., Masilamani, S. and Reddy, A., (2002): Variation in heat stress-induced antioxidant enzyme activities among three mulberry cultivars. Pl. Growth Regul .36:175-180.

De Gara, L., Locato, V., Dipierro, S. and De Pinto, M.C. (2010): Redox homeostasis in plants. The challenge of living with endogenous oxygen production.Respir. Physiol. Neurobiol. 173; S13-S19.

Dehan,K. and Tal, M.,(1978): Salt tolerance in the wild relatives of the cultivated tomato: Responses of Solariumpennellii to high salinity. Irr. Sci. 1:71-76. 
Diallinas,G., Pateraki,I., Sanmartin,M., Scossa,A., Stilianou,E., Panopoulos,N.J.and Kanellis, A.K. (1997): Melon ascorbate oxidase: cloning of a multigene family, induction during fruit development and repression by wounding. Plant Mol. Biol.34:759770 .

Farghali K.A. and Abeer A. El-Aidarous.(2014):Thermostability of chlorophylls in some native species of xerophytes. IOSR J. Agr. Vet. Sci.6: 52-65.

Fossati, J., Pautou, G. and Paul-Peltier,J.(1999): Water as resource and disturbance for wadi vegetation in a hyperarid (WadiSannur, Eastern Desert, Egypt). J. Arid Environ.43: 63-77.

$\mathrm{Fu}$, J. and Huang, B. (2001): Involvement of antioxidants and lipid peroxidation in the adaptation of two cool-season grasses to localized drought stress. Environ. Exp. Bot. 45:105-114.

Gadallah, M.A.A. (1995): Effect of waterlogging and kinetin on the stability of leaf membranes, leaf osmotic potential, soluble carbon and nitrogen compounds and chlorophyll content of Ricinusplants. Phyton 35: 199-208.

Garchery,C., Gest,N., Do,P.T., Alhagdow,M., Baldet,P.andMenard,G. (2013): A diminution in ascorbate oxidase activity affects carbon allocation and improves yield in tomato under water deficit. $\mathrm{Pl}$. Cell Environ.36: 159-175.

Grace,S.C. (2005):Phenolics as antioxidants. InN. Smirnoff (ed.) Antioxidants and Reactive Oxygen Species in Plants:141-168. Blackwell Publishing Ltd, Oxford, UK.

Guerrier, G., Strullu, D.G. (1990): Development laxesembryonnaire de poispourvus des reserves. Can. J. Bot. 68:742-746.

Havaux, M. and Tardy, F., (1999): Loss of chlorophyll with limited reduction of photosynthesis as an adaptive response of Syrian barley landraces to high-light and heat stress. Aust. J. Plant Physiol., 26: 569-578.

Hodges, D.M., DeLong, J.M., Forney, C.F., Prange, R.K., (1999): Improving the thiobarbituric acid-reactive-substances assay for estimating lipid peroxidation in plant tissues containing anthocyanin and other interfering compounds. Planta 207: 604611. 
Jones, C.G. and Hartley, S.E.( 1999): A protein competition model of phenolic allocation. Oikos 86: 27-44.

Joyce, P.S., Paleg, G. and Aspinall, D. (1984):The requirement for lowintensity light in the accumulation of proline as a response to water deficit. J.Ex. Bot. 35: 209-218.

Kar, M. and Mishra, D. (1976): Catalase, peroxidase and polyphenol oxidaseactivities during rice leaf senescence. Pl. Physiol. 57: 315319.

Kassas, M. and Batanouny, K.H. (1984):Plant ecology. InJ.L.CloudsleyThompson (eds.) Sahara Desert : 77-90. Pergamon Press, Oxford, UK.

Korkina, L.G. (2007):Phenylpropanoids as naturally occurring antioxidants: from plant defense to human health. Cel. Mol. Biol. 53(1):15-25.

Krumbein, W.C. and Sloss, L.L. (1963): Stratigraphy and sedimentation. $2^{\text {nd }}$ ed. Freeman. San Francisco.

Kusaka, M., Ohta, M. and Fujimura, T. (2005): Contribution of inorganic components to osmotic adjustment and leaf folding for drought tolerance in pearl millet. Physiol.Plantarum, 125 (4): 474.

Ladjal, M., Epron, D. and Ducrey, M., (2000): Effects of drought preconditioning on thermo tolerance of photosystem II and susceptibility of photosynthesis to heat stress in cedar seedling. Tree Physiol., 20: 1235-1241.

Levine, M., Cantilena, C.C. andDhariwal, K.R. (1995): Determination of optimal vitamin $\mathrm{C}$ requirements in humans. Am. J. Clin. Nutr.62, 1347-1356.

Lodge, J. K. (2008): Molecular actions of ascorbic acid. Curr.Top.Nutraceut. Res. $6: 1-13$.

Lutts ,S., Majerus, V. and Kinet, J.M. (1999): $\mathrm{NaCl}$ effects on proline metabolism in rice (Oryza sativa) seedlings. Physiol. Plant. 105: 450-458.

Malik, C.P. and Singh, M.B. (1980): Plant Enzymology and HistoEnzymology: A Text Manual. Kalyani Publishers, New Delhi, 286.

Manivannan,P.,Jaleel,C.A.,Sankar,B.,Kishorekumar,A.,Somasundaram,R., AlaguLakshmanan, G.M. andPanneerselvam, R. (2007): Growth, biochemical modifications and proline metabolism in Helianthus annuusL. as induced by drought stress. Colloids Surf. Biointerf. 9: 141-149. 
Marklund, S.L. and Marklund, G. (1974):Involvement of the superoxide anion radical in the oxidation of pyrogllol and convenient assay for superoxide dismutase. Eur. J. Bioch. 47: 469-474.

Maximov, N.A. (1929): The plant in relation to water. George Allen \&Unwin, Ltd., London.

Metzner,H.,Rouh,H.J.

and IntersuchungenzurSynchronisierbarKeiteinzelnerPigment mangelmu-tanten von Chlorella. Planta,65: 186-194.

Mittler, R. (2002): Oxidative stress, antioxidants, and stress tolerance. Trds. Plant Sci., 7: 405-410.

Morsy, A.A. (1996): Physiological studies on certain Egyptian medicinal plants.MS. C. Thesis., Bot. Dep. Fac. Sci., Ain Shams Univ., Cairo, Egypt.

Morsy A.A. (2002): Ecophysiological studies on certain wild plant grown in different habitats in the Egyptian deserts. Ph. D. Thesis., Bot. Dep. Fac. Sci., AinShams Univ., Cairo, Egypt.

MuKherjee, S. P. and Choudhuri, M. A. (1983): Implication of water stress - induced changes in the levels of endogenous ascorbic acid and hydrogen peroxide in Vigna seedling. Physiol. Plant. 58, $166-$ 170.

Murakeozy, E.P., Nagy, Z., Duhaze, C., Boucherean, A., and Tuba, Z. (2003): Seasonal changes in the levels ofcompatible osmolytes in three halophytic species of islandsaline vegetation in Hugary. J. Plant Physiol.,160: 395-401.

Nair, A.S., Abraham, T.K. and Jaya, D.S. (2008): Studies on the changes in lipid peroxidation and antioxidants in drought stress induced cowpea (Vignaunguiculata L.) varieties. J. Environ. Biol. 29:689691.

Neto, A.D.A., Prisco, J.T., Filho, J.E., Abreu, C.E.B. and Filho, E.G. (2006): Effect of salt stress on antioxidative enzymes and lipid peroxidation in leaves and roots of salt-tolerant and salt sensitive maize genotypes. Environ. Exp. Bot., 56: 87-94.

Nobel, P. S. (1977): Water relations and photosynthesis of a barrel cactus, Ferocactusacanthodes, in the Colorado Desert. Oecologia 27: 117133.

Nobel, P.S. and Sanderson, J. (1984): Rectifier-like activities of roots of two desert succulents. J. Exper. Bot.35: 727- 737. 
Noctor, G., Veliovic-Jovanovic, S., and Foyer, C.H. (2000): Peroxide processing in photosynthesis: antioxidant coupling and redox signaling. Philosophical transact. Roy. society B 355: 1465-1475.

Osuagwu, G.G.E andEdeoga, H.O. (2012): Effect of water stress(drought) on the mineral and vitamin content of the leaves of Gongronem alafitolium Benth. Int. J. Med. Arom. Plants, $301-309$.

Piper, C.S. (1950): Soil and plant analysis. University of Aelaide Press.Austuralia.

Reddy, M.V.B., Belkacemi, K., Corcuff, R., Castaigne and F.,Arul, J. (2000): Effect of pre-harvest chitosan sprays on post-harvest infection by Botrytis cinereaand quality of strawberry fruit. Postharvest Biol. Technol., 20: 39-51.

Richards, L.A. (1954): Diagnosis and improvement of saline and alkali soils. U.S. Dept. Agr.Handbook. 60.

Rivero, F., Dislich, H., Glöckner, G. and Noegel,A.A. (2001): The Dictyostelium family of Rho-related proteins. Nucleic Acids Res., 29: $1068-1079$.

Ryan, J., Garabet, S., Harmson, K. and Rashid, A. (1996): A soil and plant analysis. Manual adapted for the West Asia and North Africa region. ICARDA. Aleppo. Syria, $140 \mathrm{pp}$.

Salama, F.M., Kamel, M., El-Tayeh, N.A. and Hammad, S.A. (2012): Vegetation analysis, phenological patterns and chorological affinities in WadiQena, Eastern Desert, Egypt. Afric. J. Ecol .50: 193-204.

Scholz, F.G., Bucci, S.J., Arias, N., Meinzer, F.C.and Goldstein, G. (2012): Osmotic and elastic adjustments in cold desert shrubs differing in rooting depth: coping with drought and subzero temperatures. Oecologia.; 170: 885-897.

Sies, H.and Stahl, W. (1995): Vitamins E and C, $\beta$-carotene, and other carotenoids as antioxidants. Am. J. Clin. Nutr.,62; 1315-1321.

Smirnoff, N. (1998): Plant resistance to environmental stresss. Curr.Opin.Biotechnol. 9:214-219

Täckholm, V. (1974): Student Flora of Egypt, $2^{\text {nd }}$ ed. Cairo University.

Takahama ,U. and Oniki T. (1994): The association of ascorbate and ascorbate oxidase in the apoplast with IAA-enhanced elongation of epicotyls from Vignaangularis. Pl. Cell Physiol.35: 257-266. 
Udden, J.A. (1914): Mechanical composition of clastic sediments.B. Geol. Soc.Amer.25:655-744.

Velikova, V., Yordancv, I .and Edreva, A. (2000): Oxidative stress and some antioxidant systems in acid rain-treated bean plants. Protective role of exogenous polyamines.Plant Sci.151: 59-66.

Waly, N. M.,Al-Ghamdi, F.A. and Al-Shamrani, R. I., (2011): Developing methods for anatomical identification of the genus Zygophyllum $\mathrm{L}$. (Zygophyllaceae) in Saudi Arabia. J.Life Sci.8(3):451-459.

Wentworth, C. K. (1922): .Ascale of grade and class terms for clasticsediments . J. Geol. 30:377-392.

Wingler, A., Quick,W.P., Bungard, Bailey, K. J., Lea, P. J. and Leegood, R.C., (1999): The role of photorespiration during drought stress; an analysis utilizing barley mutants with reduced activities of photorespiratory enzymes. Pl. Cell Environ.,22:361-373.

Yiu, J.C., Liu, C.W., Fang, D.Y.and Lai, Y.S. (2009): Waterlogging tolerance of Welsh onion (Allium fistulosumL.) enhanced by exogenous spermidine and spermine. Pl. Physiol.Biochem.47: 710-716.

Zahran, M.A. and Willis A.J. (1992):The vegetation of Egypt. Chapman and Hall Publication, London, UK.

Zaki ,V.A. (1995):Ecophsiological studies on plant-soil relationships in an African arid environment under some stress conditions. Ph.D. Thesis, Natural.Resources Dept. Institute of African Research and Studies, Cairo, Egypt.

Zhan, H.X., Chang, Z.J. Wei, A.L., Zhang X.J. and Li, X. (2011): Impact of drought to wheat. Physiol. Index.39(10): 1049- 1051.

Zhou, Z.J.; Su, P.X.; Xie, T.T.; Zhang, H.N. and Li, S.J. (2013): Physiological and biochemical regulation mechanisms for drought adaption in typical desert shrubs. J. Chemical \&Pharmaceu. Res.5(11):671-677.

Zhu, J.J., Zhang, J.L., Liu, H.C. and Cao, K.F., (2009a): Photosynthesis, non photochemical pathways and activities of antioxidant enzymes in a resilient evergreen oak under different climatic conditions from a valley-savanna in Southwest China. Physiol. Pl.135:62-72.

Zhu, Z.B., Liang, Z.S. and Han, R.L. (2009b):Saikosaponin accumulation and antioxidative protection in drought-stressed Bupleurumchinense DC plants. Environ. Exp. Bot.66: 326-33. 